\title{
Banding P to Improve Fertilizer Use Efficiency of Lettuce
}

\author{
C.A. Sanchez, S. Swanson, and P.S. Porter \\ University of Florida, IFAS, Everglades Research and Education Center, P. O. Box 8003, Belle \\ Glade, FL 33430 \\ Additional index words. Lactuca sativa, fertilizer placement, soil testing, plant analysis
}

\begin{abstract}
Five field experiments were conducted from 1986 to 1989 to compare broadcast and band $P$ fertilization of crisphead lettuce (Lactuca sativa $L$.) on Histosols. Rates of $P$ were $0,50,100,200$, and $300 \mathrm{~kg} P / \mathbf{h a}$ applied broadcast or banded. Broadcast $P$ was surface-applied and disked into the soil 1 day before bedding and planting. Banded $P$ was placed in strips $8 \mathrm{~cm}$ wide, $5 \mathrm{~cm}$ below the lettuce seeds at planting. Lettuce yields were significantly $(P<0.01)$ increased by $P$ rate in all experiments. However, significant rate-by -placement interactions indicated that response of lettuce to $P$ varied by placement. Lettuce yields were generally optimized with a band $P$ rate one-third of that required with broadcast placement. Analysis of soil samples collected in the lettuce bed after fertilization indicated that banded $P$ increased available $P$ in the lettuce root zone compared to broadcast fertilization. Lettuce leaf $P$ concentration increased with $P$ rate and generally was greater when $P$ was banded. The critical concentration of $P$ in lettuce leaf tissue at the six- to eight-leaf stage was $0.37 \%$. Banding $P$ fertilizer did not reduce the availability of other essential nutrients, as indicated by tissue analysis.
\end{abstract}

More than $90 \%$ of the lettuce produced in the eastern United States and much of the lettuce produced in Canada is grown on Histosols (organic soils) (Lucas, 1982). Because lettuce produced on these soils requires relatively large amounts of plantavailable $\mathrm{P}$ for optimal yield and quality (Sanchez and Burdine, 1988), it is imperative that management strategies that improve the efficiency of $\mathrm{P}$ fertilization be rigorously evaluated. For example, concern has been expressed that P-enriched drainage waters from agriculture fields in southern Florida may affect the ecology of Lake Okeechobee and the Everglades Water Conservation Area-National Park ecosystem (Swift and Nicholas, 1987). Similar environmental concerns about $P$ have been expressed in other regions where Histosols are used extensively for vegetable production (Miller, 1979; Duxbury and Peverly, 1978). Improved fertilizer management offers the best means to control P-loading of drainage waters from these soils (Cogger and Duxbury, 1984).

The benefits of banding $\mathrm{P}$ for various agronomic (Randall and Hoeft, 1988) and horticultural (Davis et al., 1956; Locascio et al., 1960) crops have long been recognized. However, because of concern that lettuce might be adversely affected by high salt concentration near the rooting zone (Grogan and Zink, 1956), fertilizer banding is not widely practiced for lettuce production in southern Florida. Preliminary studies, using selected combinations of broadcast and banded mixed (N-P-K) fertilizers, indicated that lettuce was not adversely affected by banded fertilizer, and these data suggested that the efficiency of fertilization can be improved substantially by banding at least part of the fertilizer (Guzman et al., 1987). However, the possibility of banding all the $\mathrm{P}$ required has not been investigated. Furthermore, there is no information available on the relative efficiency of broadcast and band fertilization for lettuce; hence, we have no criteria by which to make alternate banded-P fertilizer recommendations. More than $95 \%$ of all $\mathrm{P}$ used for lettuce production on Florida Histosols is applied broadcast on the basis

\footnotetext{
Received for publication 12 July 1989. Univ. of Fla. Expt. Sta. Journal series no. 10068. We thank South Bay Growers Inc. for providing the lettuce production fields used in these studies and some of the crop care. The cost of publishing this paper was defrayed in part by the payment of page charges. Under postal regulations, this paper therefore must be hereby marked advertisement solely to indicate this fact.
}

of preplant soil test fertilizer recommendations (Sanchez, 1989). The objectives of studies reported herein were to compare the relative efficiency of broadcast and banded $\mathrm{P}$, and develop criteria by which to make alternative band $\mathrm{P}$ fertilizer recommendations for lettuce.

\section{Materials and Methods}

Five field experiments were conducted during 1986 to 1988 to compare broadcast and band $\mathrm{P}$ rates for crisphead lettuce. The planting dates, harvest dates, weather conditions during each experiment, and soil properties at each site are shown in Table 1. Experiments 1, 2, and 3 were conducted on a Pahokee muck (euic, hyperthermic Lithic Medisaprist). Experiments 4 and 5 were conducted at two separate locations on a Terra Ceia muck (euic, hyperthermic Typic Medisaprist). Broadcast $\mathrm{P}$ rates were $0,100,200$, and $300 \mathrm{~kg} \mathrm{P} / \mathrm{ha}$, and banded $\mathrm{P}$ rates were $0,50,100,200$, and $300 \mathrm{~kg} \mathrm{P} / \mathrm{ha}$ in Expt. 1. Broadcast and banded $\mathrm{P}$ rates were $0,50,100,200$, and $300 \mathrm{~kg} \cdot \mathrm{ha}^{-1}$ for all remaining experiments. Triple superphosphate was the $\mathrm{P}$ source. Both broadcast and band $\mathrm{P}$ treatments were carefully applied by hand to individual plots. Broadcast $\mathrm{P}$ was surface-applied and disked into the soil 1 day before bedding and planting. The banded $\mathrm{P}$ was placed $5 \mathrm{~cm}$ below the lettuce seeds in strips 8 $\mathrm{cm}$ wide at the time of planting. Plots were $3.66 \times 15.24 \mathrm{~m}$ and treatments were arranged in randomized complete-block designs with four replications. The $\mathrm{K}$ was applied based on soil test (Sanchez, 1989) at rates of 200, 150, 250, 100, and 225 $\mathrm{kg} \cdot \mathrm{ha}^{-1}$ in Expts. 1 through 5, respectively. In all experiments $\mathrm{Zn}, \mathrm{Mn}$, and B were applied at 9, 9, and $2 \mathrm{~kg} \cdot \mathrm{ha}^{-1}$, respectively. Micronutrients and $\mathrm{K}$ were applied preplant broadcast and disked into the soil before planting. Nitrogen was applied at $50 \mathrm{~kg} \cdot \mathrm{ha}^{-1}$ as a sidedress at the six-leaf stage. Water was supplied using subsurface irrigation from field ditches by maintaining a water table $\approx 60 \mathrm{~cm}$ below the soil surface (Snyder et al., 1978).

'South Bay' crisphead lettuce was seeded in elevated doublerow beds on $0.9-\mathrm{m}$ centers and thinned at the four-leaf stage to a 25 -cm in-row spacing for a population of $\approx 60,000$ plants $/$ ha. Heads were harvested from $6 \mathrm{~m}$ of each of two rows per bed and marketable yields were determined after grading, according to standard marketing criteria (USDA, 1973).

The oldest sound leaf from each of 15 plants was collected 
Table 1. Planting dates, harvest dates, weather conditions, and soil properties during five field experiments conducted in 1986 , 1987 , and 1988.

\begin{tabular}{|c|c|c|c|c|c|c|c|c|c|}
\hline \multirow[b]{4}{*}{ Experiment } & & & \multicolumn{4}{|c|}{ Weather conditions } & \multirow{2}{*}{\multicolumn{3}{|c|}{ Soil properties }} \\
\hline & \multirow[b]{2}{*}{ Dates of cropping } & & \multirow{3}{*}{$\begin{array}{l}\text { Mean } \\
\text { temp } \\
\left({ }^{\circ} \mathrm{C}\right) \\
\end{array}$} & \multirow{3}{*}{$\begin{array}{c}\text { Solar } \\
\text { radiation } \\
\left(\mathrm{W} \cdot \mathrm{m}^{-2}\right)\end{array}$} & \multirow{3}{*}{$\begin{array}{c}\text { Rainfall } \\
(\mathrm{cm})\end{array}$} & \multirow{3}{*}{$\begin{array}{c}\text { Pan } \\
\text { evaporation } \\
\text { (cm) } \\
\end{array}$} & & & \\
\hline & & & & & & & \multirow[b]{2}{*}{$\mathrm{pH}^{\mathrm{z}}$} & \multirow{2}{*}{$\begin{array}{c}\mathrm{CaCO}_{3}{ }^{\mathrm{y}} \\
(\%)\end{array}$} & \multirow{2}{*}{$\begin{array}{l}\text { Soil-test } \mathrm{P}^{\mathrm{x}} \\
\left(\mathrm{mg} \cdot \mathrm{dm}^{-3}\right)\end{array}$} \\
\hline & Planting & Harvest & & & & & & & \\
\hline 1 & 12 Nov. 1986 & 22 Jan. 1987 & 22.2 & 111 & 15.4 & 19.6 & 6.5 & 0.31 & 1.7 \\
\hline 2 & 4 Mar. 1987 & 5 May 1987 & 17.5 & 175 & 14.8 & 33.4 & 5.9 & 0.0 & 2.2 \\
\hline 3 & 18 Dec. 1987 & 7 Mar. 1987 & 16.7 & 140 & 14.8 & 25.3 & 5.9 & 0.0 & 2.6 \\
\hline 4 & 7 Jan. 1988 & 18 Mar. 1987 & 16.1 & 149 & 16.3 & 25.0 & 5.9 & 0.53 & 3.9 \\
\hline 5 & 18 Oct. 1988 & 22 Dec. 1988 & 18.9 & 126 & 5.6 & 21.7 & 6.2 & 1.90 & 9.3 \\
\hline
\end{tabular}

z1 soil : 2 water $(\mathrm{v} / \mathrm{v})$ with glass electrode while stirring.

yetermined by $\mathrm{CO}_{2}$ evolution method.

$\mathrm{x} 1$ soil : 12.5 water $(\mathrm{v} / \mathrm{v})$ extraction.

in each plot at the six- to eight-leaf stage for mineral analysis. Plant material was dried at $60 \mathrm{C}$ for $48 \mathrm{hr}$. Nitrogen was determined by a micro-Kjeldahl method (Bremner and Mulvaney, 1982). After wet-ashing (Wolf, 1982), $\mathrm{P}$ was determined colorimetrically, and $\mathrm{K}, \mathrm{Ca}, \mathrm{Mg}, \mathrm{Zn}, \mathrm{Fe}, \mathrm{Mn}$, and $\mathrm{Cu}$ by atomic absorption spectrophotometer. Soil samples were taken before planting and 30 days after fertilizer application. The samples collected 30 days after fertilization were taken at random from within the lettuce bed to a depth of $15 \mathrm{~cm}$. These samples were analyzed for water-soluble P by methods described by Sanchez (1989).

Data were subjected to analysis of variance using SAS-GLM (SAS, 1982). The relative efficiency of broadcast and band $P$ fertilization was evaluated by using the concurrent Mitscherlich model described by Engelstead and Khasawneh (1969). The equation is as follows: $\ln (1-\mathrm{y} / \mathrm{A})=\ln \mathrm{a}-\mathrm{C}_{1} \mathrm{X}_{\mathrm{BR}}-\mathrm{C}_{2} \mathrm{X}_{\mathrm{BA}}$, where: $\mathrm{a}$ is a constant; $\mathrm{y}$ is the observed yields; $\mathrm{A}$ is the limiting yield; $X_{B R}$ is the rate of $P$ applied broadcast, $X_{B A}$ is the $P$ rate applied by band, and $c_{1}$ and $c_{2}$ are the Mitscherlich coefficients for broadcast and band-applied $\mathrm{P}$, respectively. The $\mathrm{P}$ rate for $98 \%$ maximum for broadcast or banded $\mathrm{P}$ was found by setting $\mathrm{X}_{\mathrm{BA}}$ or $\mathrm{X}_{\mathrm{BR}}$ to zero, respectively, as follows: $\mathrm{y} / \mathrm{A}=1-\mathrm{ae}^{-\mathrm{C}} \mathrm{i}^{\mathrm{x}} \mathrm{i}$, where $x_{i}$ and $c_{i}$ are the $P$ rate and coefficient within a placement method, respectively. The $\mathrm{P}$ rates for $98 \%$ maximum yield ( $\mathrm{y} /$ $\mathrm{A}=0.98)$ were calculated by $\mathrm{x}_{\mathrm{i}}=-\ln (0.02 / \mathrm{a}) / \mathrm{c}_{\mathrm{i}}$.

\section{Results and Discussion}

Average marketable lettuce yields ranged from 15.1 to 50.2 $\mathrm{t} \cdot \mathrm{ha}^{-1}$. The low yield in Expt. 5 was presumably the result of moisture stress during the growing period. Only $5.6 \mathrm{~cm}$ of precipitation occurred during this period, and the field used in this experiment was subsequently found to have a water-restricting layer (hard pan) $30 \mathrm{~cm}$ below the soil surface that limited the effectiveness of subsurface irrigation.

Lettuce yields were significantly increased by $\mathrm{P}$ rates in all experiments (Fig. 1). The increase in marketable yield was due to an increase in the number of heads of marketable grade and an increase in average weight of trimmed heads (data not shown). The rate by placement interaction was significant in Expts. 1, 3,4 , and 5 , indicating that response of lettuce to $\mathrm{P}$ varied with placement. To evaluate these interactions, individual response equations were determined for each method of placement (Fig. 1 and Table 2). A comparison of several response models indicated that the Mitscherlich response equation provided the best fit of the data as indicated by the coefficient of determination and an analysis of the residuals (data not shown).

There are two ways to evaluate the relative efficiency of

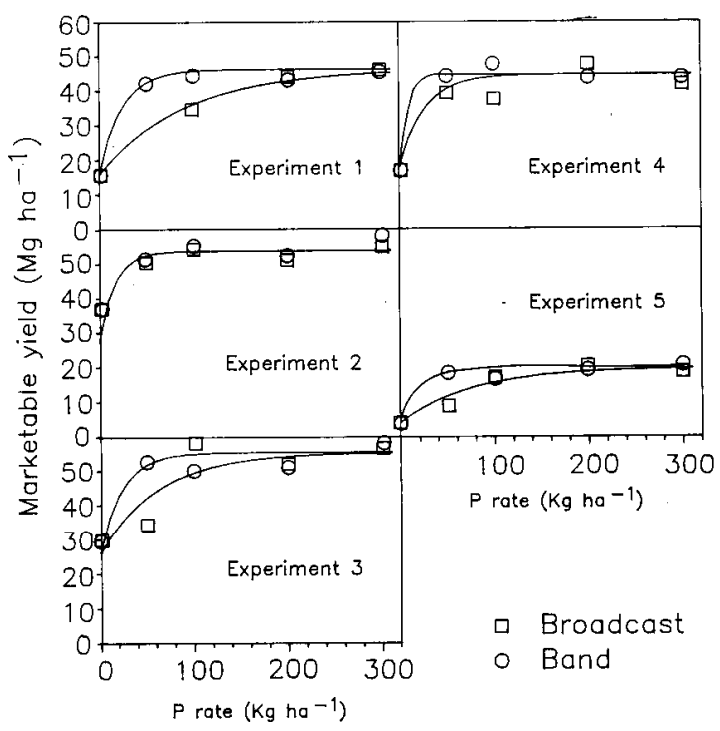

Fig. 1. Marketable yield of crisphead lettuce as affected by $P$ rate and placement. Symbols show observed mean yield, and lines are yield predicted by the Mitscherlich model.

Table 2. Lettuce yield response as a function of broadcast and banded $P$ for five experiments.

\begin{tabular}{cllcccc}
\hline \hline & & \multicolumn{3}{c}{$\begin{array}{c}\text { Regression } \\
\text { coefficients }\end{array}$} & \multirow{2}{*}{$\begin{array}{c}\text { P rate required } \\
\text { for } 98 \%\end{array}$} \\
\cline { 3 - 6 } Experiment & Placement & A & a & c & $\mathrm{R}^{2}$ & maximum yield \\
\hline \multirow{2}{*}{1} & Broadcast & 46.3 & 0.66 & 0.011 & 0.91 & $300^{\mathrm{y}}$ \\
& Band & 46.3 & 0.66 & 0.041 & 0.80 & 86 \\
2 & No significant & & & & & \\
& difference & 53.9 & 0.49 & 0.060 & 0.74 & 53 \\
3 & Broadcast & 55.5 & 0.53 & 0.016 & 0.65 & 204 \\
& Band & 55.5 & 0.53 & 0.042 & 0.72 & 78 \\
4 & Broadcast & 44.5 & 0.60 & 0.037 & 0.66 & 113 \\
& Band & 44.5 & 0.60 & 0.110 & 0.80 & 31 \\
5 & Broadcast & 20.0 & 0.79 & 0.013 & 0.82 & 283 \\
& Band & 20.0 & 0.79 & 0.042 & 0.72 & 88 \\
\hline
\end{tabular}

${ }^{2}$ Mitscherlich parameters where $\mathrm{y}$ is observed yield, $\mathrm{A}$ is limiting yield, $a$ is a constant, and $c$ is the efficiency coefficient.

${ }^{y}$ Maximum occurred outside range of treatments and thus $300 \mathrm{~kg} \cdot \mathrm{ha}^{-1}$ was used as the maximum rate.

broadcast vs. band application of $\mathrm{P}$ fertilizer. One way is to directly compare the "c" coefficients generated by the Mitscherlich response models (Table 2). Theoretically, these values are efficiency coefficients that describe the rate at which alter- 

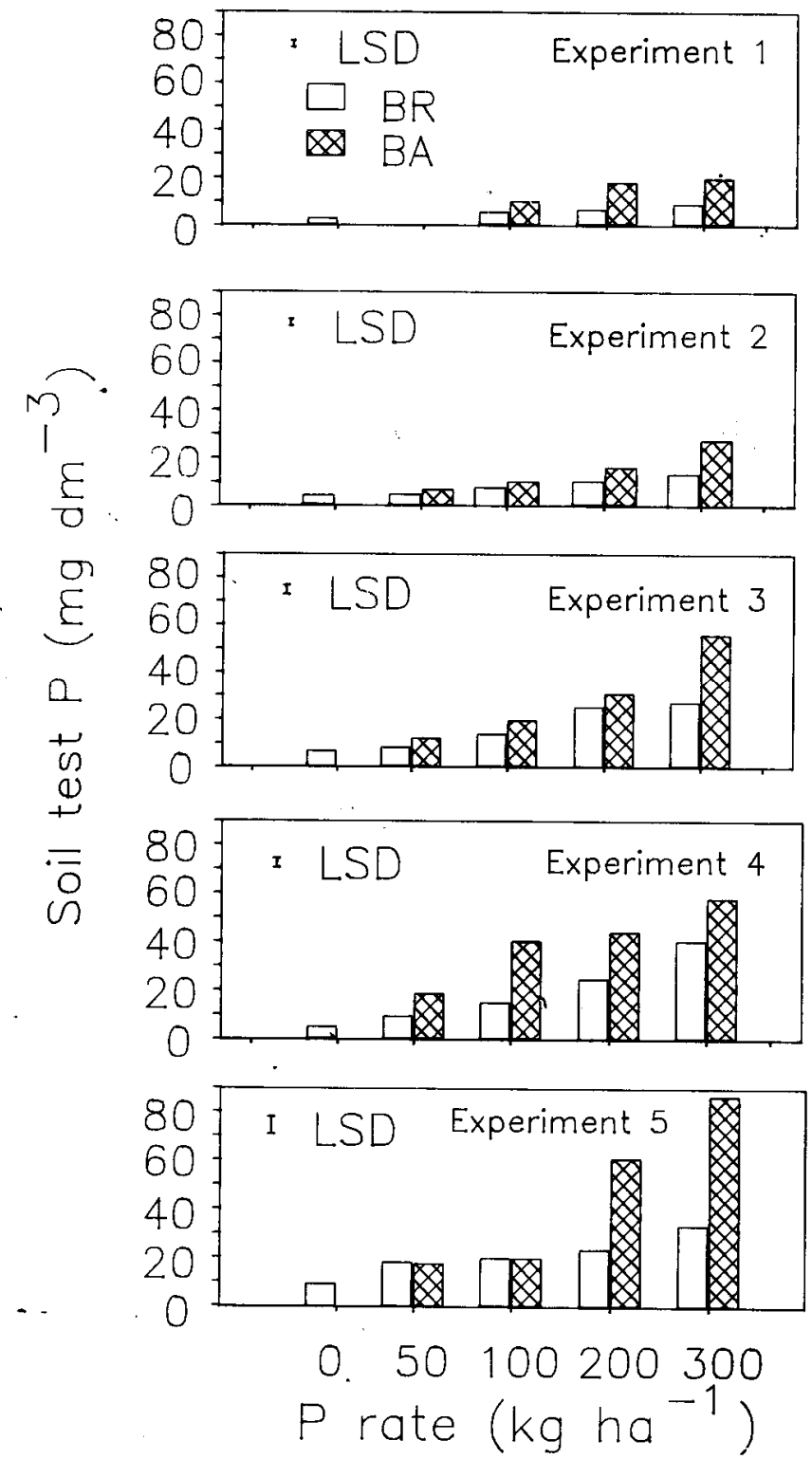

Fig. 2. Water-soluble $\mathrm{P}$ levels in the lettuce bed as affected by $\mathrm{P}$ rate and placement. Significant $(P<0.01)$ linear response to rate in all years. LSDS are for the placement comparisons.

native technologies, in this case fertilizer placement, approach a common limiting yield (White et al., 1956). Comparing coefficients showed that band P fertilization was 3.5, 2.6, 3.6, and 3.2 times more effective than broadcast fertilization in Expts. $1,3,4$, and 5 , respectively.

A more practical approach to evaluate fertilizer use efficiency is to compare the $\mathrm{P}$ rates required for maximum or near-maximum yield. Because the Mitscherlich model does not produce a clear maximum, we calculated the fertilizer rates that produced 98\% maximum yield (Ware et al., 1982). Overall, band P achieved 98\% maximum yield with an average of one-third the $\mathrm{P}$ rate required by broadcast (Table 2). The exception was Expt. 2, where lettuce yield response was largely due to the first increment of P fertilizer, regardless of placement method. The results of this experiment were surprising because years of soil test calibration research indicate that lettuce grown on this soil would normally have responded to a broadcast $\mathrm{P}$ rate of $200 \mathrm{~kg} \cdot \mathrm{ha}^{-1}$ (Sanchez and Burdine, 1988). The response of lettuce to fertil-
Table 3. Concentration of $P$ in lettuce leaf tissue samples collected at the six- to eight-leaf stage in five experiments.

\begin{tabular}{|c|c|c|c|c|c|}
\hline \multirow{2}{*}{$\begin{array}{l}\text { P rate } \\
\left(\mathrm{kg} \cdot \mathrm{ha}^{-1}\right)\end{array}$} & \multicolumn{5}{|c|}{ Experiment } \\
\hline & 1 & 2 & 3 & 4 & 5 \\
\hline & \multicolumn{5}{|c|}{$(\% P, d r y$ wt basis $)$} \\
\hline 0 & 0.17 & 0.27 & 0.31 & 0.31 & 0.28 \\
\hline 50 & $--^{x}$ & 0.31 & 0.37 & 0.36 & 0.46 \\
\hline 100 & 0.33 & 0.33 & 0.39 & 0.39 & 0.47 \\
\hline 200 & 0.38 & 0.35 & 0.41 & 0.41 & 0.46 \\
\hline 300 & 0.45 & 0.36 & 0.40 & 0.41 & 0.50 \\
\hline Significance & $\mathrm{L}^{* *}$ & $\mathrm{~L}^{* *}$ & $\mathrm{~L}^{* *} \mathrm{Q}^{*}$ & $\mathrm{~L}^{* *} \mathrm{Q}^{*}$ & $\mathrm{~L}^{* *}$ \\
\hline \multicolumn{6}{|l|}{$P$ placement } \\
\hline Broadcast & 0.32 & 0.32 & 0.37 & 0.37 & 0.42 \\
\hline Band & 0.35 & 0.32 & 0.39 & 0.38 & 0.44 \\
\hline \multicolumn{6}{|l|}{ Significance } \\
\hline $\mathrm{P}$ placement & ** & NS & $*$ & NS & $* *$ \\
\hline$P$ rate $\times$ placement & NS & NS & NG- & $*$ & NS \\
\hline
\end{tabular}

${ }^{\mathrm{z}}$ The $50 \mathrm{~kg}$ P/ha band rate in Expt. 1 was excluded from presentation in this table to preserve factorial treatment structure.

$\mathrm{NS}, *, * *$ Nonsignificant or significant at 0.05 and 0.01 , respectively.

izer has been shown to depend on weather conditions (Greenwood et al., 1974), and it is possible that under the near-ideal growing conditions prevalent during Expt. 2, lettuce used available P more efficiently. Furthermore, high evaporation coupled with the moderately low soil pH in Expt. 2 may have resulted in a continual flux of $\mathrm{P}$ into the lettuce rooting zone with the upward mass movement of water supplied by seepage irrigation (Table 1).

The results of Expt. 2 do not confuse the issue of fertilizer placement as much as they confound the whole principle of predicting crop fertilizer needs based on preplant soil test. Nevertheless, the prediction of crop fertilizer requirements from pre-plant soil test is based on long-term probability and risk considerations. Therefore, just as the application of $200 \mathrm{~kg} \mathrm{P} /$ ha would have been the appropriate broadcast fertilization practice to ensure optimal lettuce yields, the application of one-third this rate applied in a band would have been an appropriate alternative to ensure optimal yields with improved fertilizer use efficiency.

Previous work with agronomic crops has generally shown that the relative efficiency of banded vs. broadcast fertilization decreases as soil-test P levels increase (Randall and Hoeft, 1988). This trend was not observed in these experiments with lettuce, possibly because short-season vegetables, such as lettuce, have a less-extensive root system than most agronomic crops and respond to P placement differently. More than $95 \%$ of the lettuce root system remains in the bed volume (R.T. Nataga, personal communication), and analysis of soil samples collected in the bed 30 days after fertilization indicated that band placement of $\mathrm{P}$ increased available $\mathrm{P}$ levels in this zone compared to broadcast fertilization (Fig. 2).

Banding of $\mathrm{P}$ fertilizer did not affect the leaf tissue composition of $\mathrm{N}, \mathrm{K}, \mathrm{Ca}, \mathrm{Mg}, \mathrm{Fe}, \mathrm{Zn}, \mathrm{Mn}$, and $\mathrm{Cu}$ (data not shown). The concentration of $\mathrm{P}$ in lettuce leaves at the six- to eight-leaf stage increased with $P$ rate in all experiments (Table 3 ). In Expts. 1, 3, and 5, the leaf $\mathrm{P}$ concentrations also were affected by placement. In Expt. 4, the rate x placement interaction was significant where the $\mathrm{P}$ concentration was increased by band placement, but only at $50 \mathrm{~kg} \mathrm{~N} / \mathrm{ha}$. During this season, the P concentration in the lettuce leaf tissue was $0.33 \%$ and $0.39 \%$ for broadcast and band P, respectively, with $50 \mathrm{~kg} \mathrm{P} / \mathrm{ha}$.

Generally, all leaf tissue P concentrations were $<0.60 \%$, which 


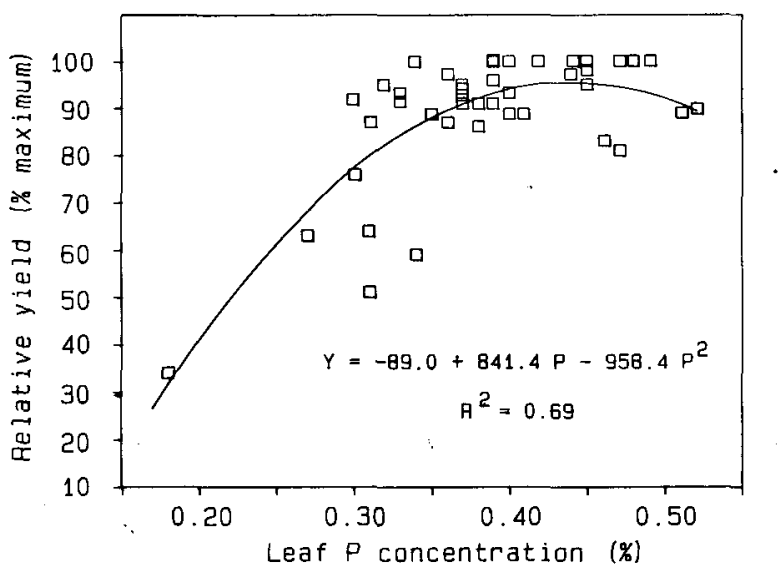

Fig. 3. Relative yield of lettuce as affected by leaf tissue $P$ concentration at the six- to eight-leaf growth stage.

has been used as the critical leaf-tissue concentration by others (Geraldson et al., 1973; Smith and Scaife, 1973). The relationship between the relative yield of lettuce and leaf-tissue P concentration across all experiments was used to calculate the critical $\mathrm{P}$ concentration (Fig. 3). A critical concentration of $0.37 \%$ was calculated by solving the quadratic equation at $98 \%$ maximum yield. This value is only slightly below the value of $0.44 \%$ calculated previously from a data base generated largely with the New York cultivars Ithaca and Minetto (Sanchez et al., 1988) and the value of $0.40 \%$ calculated for 'South Bay' using growth-rate analysis (Beverely, 1984).

In conclusion, these studies indicate that banding is indeed a viable strategy for reducing the amount of $\mathrm{P}$ used for lettuce produced on Histosols. Overall, results indicate that optimal lettuce yields can be achieved with banded $\mathrm{P}$ rates one-third of those required broadcast without any adverse effects on lettuce yield. Because Histosols used extensively for crop production are often hydrologically linked to environmentally sensitive wetlands, additional research aimed at improving fertilizer use efficiency for other vegetables through banding appears justified.

\section{Literature Cited}

Beverely, R.B. 1984. Nutritional survey of the Everglades vegetable industry. Proc. Fla. State Hort. Soc. 97:201-205.

Bremner, J.M. and C.S. Mulvaney. 1982. Nitrogen-total, p. 596-624: In A.L. Page (ed.). Methods of soil analysis. Part 2. Agronomy, vol. 9.

Cogger, C. and J.M. Duxbury. 1984. Factors affecting P losses from cultivated" organic soils. J. Environ. Qual. 13:111-114.

Davis, J.F., W.C. Hulbert, C.M. Hansen, and L.N. Shephard. 1956. The effects of fertilizer placement on the yield of onions and spinach grown on organic soils. Mich. Agr. Expt. Sta. Quart. Bul. 39:25-

Duxbury, J.M. and J.M. Peverely. 1978. Nitrogen and phosphorus losses from organic soils. J. Environ. Qual. 7:566-570.
Engelstad, O.P. and F.E. Khasawneh. 1969. Use of a concurrent Mitscherlich model in fertilizer evaluation. Agron: J. 61:473-474.

Geraldson, C.M., G.R. Klacan, and O.A. Lorenz. 1973. Plant analysis as an aid for fertilizing vegetable crops, p. 365-379. In: L.M. Walsh and J.M. Beaton (eds.). Soil testing and plant analysis. Soil Sci. Soc Amer., Madison, Wis.

Greenwood, D.J., T.J. Cleaver, and K.B. Niendorf. 1974. Effects of weather conditions on the response of lettuce to applied fertilizers. J. Agr. Sci. 82:217-232.

Grogan, R.G. and F.W. Zink. 1956. Fertilizer injury and its relationship to several previously described diseases of lettuce. Phytopathology 46:416-422.

Guzman, V.L., C.A. Sanchez, and R.E. Lucas. 1987. Banding fertilizers for improved fertilizer efficiency for lettuce on Everglades Histosols. Proc. Fla. State Hort. Soc 100:200-203.

Locascio, S.J., G.F. Warren, and G.E. Wilcox. 1960. The effect of phosphorus placement on uptake of phosphorus and growth of direct seeded tomatoes, Amer. Soc Hort. Sci. Proc. 73:503-514.

Lucas, R.E. 1982. Organic soils (Histosols). Formation, distribution, physical and chemical properties and management for crop production. Michigan State Univ. Press, East Lansing. Res. Rpt. 435.

Miller, M.H. 1979. Contribution of nitrogen and phosphorus to subsurface drainage waters from intensively cropped mineral and organic soils in Ontario. J. Environ. Qual. 8:42-48.

Randall, G.W. and R.G. Hoeft. 1988. Placement methods for fertilizers: A review. J. Prod. Agr. 1:70-78.

Sanchez, C.A. 1989. Soil testing and fertilizer recommendations for crop production on organic soils in Florida. Univ. Fla. Bul. 876.

Sanchez, C.A. and H.W. Burdine. 1988. Response of lettuce to soil test $\mathrm{P}$ and K levels. Soil Crop Sci. Soc Fla. Proc. 47:52-55.

Sanchez, C.A., H.W. Burdine, V.L. Guzman, and C.B. Hall. 1988. Yield, quality, and leaf nutrient composition of crisphead lettuce as affected by N, P, and K on Histosols. Proc. Fla. State Hort. Sci. 101:346-350.

SAS Institute, Inc. 1982. SAS user's guide: Statistics: 1982 ed. SAS Institute, Inc., Cary, N.C.

Smith, R., M.A. Scaife. 1973. The phosphorus requirements of lettuce. 1. Use of $\mathrm{P}$ intensity estimates to predict response curve. $\mathrm{J}$. Agr. Sci. 80:111-117.

Snyder, G.H., H.W. Burdine, J.R. Crockett, G.J. Gascho, D.S. Harrison, G. Kidder, J.W. Milshoe, D.L. Myhre, F.M. Pate, and S.F. Shih. 1978. Water table management for organic soil conservation and crop production in the Florida Everglades. Univ. Fla. Bul. 801.

Swift, D.R. and R.B. Nicholas. 1987. Periphton and water quality relationships in the Everglades Water Conservation Areas. South Fla. Water Mgt. Dist. Tech. Rpt. 87-2.

USDA. 1973. USDA standards for grades of lettuce. Agriculture Marketing Service. Washington, D.C.

Ware, G.O., K. Ohiki, and L.C. Moon. 1982. The Mitscherlich plant growth response model for determining critical nutrient deficiency levels. Agron. J. 74:88-91.

White, R.F., C.A. Black, O. Kempthorne, and J.R. Webb. 1956. Fertilizer evaluation: H. Estimation of availability coefficients. Soil Sci. Soc Amer. Proc. 20:179-186.

Wolf, B. 1982. A comprehensive system of leaf analyses and its use for diagnosing crop nutrient status. Commun. Soil Sci. Plant Anal. 13:1035-1059. 